\title{
Producing Precarity: The Temporary Staffing Agency in the Labor Market
}

\author{
Emine Fidan Elcioglu
}

Published online: 27 February 2010

(C) The Author(s) 2010. This article is published with open access at Springerlink.com

\begin{abstract}
On the basis of fieldwork in a temporary staffing agency (TSA), I argue that while temp agencies may provide transitional mobility for jobseekers, in the long run the TSA systematically exploits and reproduces structural vulnerability in the labor market. The agency creates a core of permanent temporary workers separate from the periphery of surplus workers, such that the former is given priority in job allocation. The staffing agency can use alliances with institutions such as private correctional facilities to control its peripheral workers. At the same time, highly valued core workers also face precarious conditions when they are barred from job mobility and their wages are capped. The agency further reinforces precariousness during the moment of work by extending the agency's surveillance to client sites.
\end{abstract}

Keywords Precarious work - Temporary help agencies · Temporary work · Flexible work · Structural vulnerability

I'm available on Monday, I'm available on Tuesday, I'm available on Wednesday, I'm available on Thursday, I'm available on Friday and even the weekend. I'm available in the morning. I'm available in the afternoon. I'm even [sigh] available in the evening. I have my chef coat, I have my white shirt, I have my chef pants, I have my shoes, I have my knives [cooks need their own knives for certain job assignments]. I'm available. Call me. (voicemail left for Instant People staff by Timothy, an Instant People employee)

Man! At [a biotechnology client company] they automatically give you 3 days off if you have a death in the family. [In an exaggerated voice] At Instant People, you better have the death certificate...AND a picture of you next to the coffin [to get excused from a job assignment]. (Darren, Instant People account manager joking with Sean, owner)

E. F. Elcioglu $(\bowtie)$

Department of Sociology, UC Berkeley, 410 Barrows Hall, Berkeley, CA 94720-1980, USA

e-mail: fidan@berkeley.edu 
It's hard not to be charmed by Adeline's warm and bubbly personality.

But intermittently I hear her sigh into the phone as she reflects back on October 7th, when she lost her regular temporary position working as a grill cook at a local college, serving hamburgers, chicken patties, and grilled cheese sandwiches to hungry college students. It was a fast-paced and tiring job, requiring her to be on her feet for the entire day, but her manager "loved" her. After a month of this apparent regularity in a place known for its demanding management and high employee turnover, her manager's approving evaluation of Adeline's job performance meant a lot to her. She harbored hopes that the company would want to take her on as a permanent employee. After all, it was hard enough for " 50 -year olds like [her]self" to find secure work. But on October 6th, having worked a long and arduous shift during her weekend job at a catering company, she started to feel sharp pain in her leg. The next day the pain had spread upward and her leg was noticeably swollen. She called Instant People (IP), the food and hospitality temp agency where she was employed and where I was doing my ethnographic work. She wanted to see if she could have another grill cook replace her for 1 day at the college. I answered the phone. I failed to find a replacement 3 hours before the job was scheduled to begin, at a site that is fairly inaccessible by public transportation. After some hesitation, she decided to "hobble into [her] car" and go to work. Her manager would be angry, she had told me during our phone conversation, and she simply could not afford to "lose this job, you know?" An hour later, under the influence of painkiller medication, she crashed her car into a pole, injuring her head and incurring costly damage to her ten-year-old Toyota Corolla.

Nearly 2 months later, we're chatting on the phone. After I introduce myself, she expresses pleasure that someone from Instant People has called to check in on her. Her leg is better, but she can't stand on her feet for more than 2 hours at a time, so she hasn't tried to negotiate with IP staff to get back her position at the college. She's thinking about moving in with her daughter so she can save on rent, although with a baby granddaughter on the way, it might be a "squeeze." She chuckles for a moment, then pauses. "I sure hope the economy gets better," she concludes in a more somber tone. While she's still an "active" employee of IP, the agency hasn't called her with any positions since her accident. "They tell me there are no jobs right now. But I keep my phone nearby...you never know," she tells me, her voice quieter.

Adeline's story is not unique. The state of precariousness increasingly characterizes the [under] employment experiences of the "unskilled" and skilled alike who daily toil and wait to toil in what Paul Osterman (1999) has termed the "new economy." Loïc Wacquant (2008a) has identified the precariat as the "insecure fringes of the new proletariat...made up of heterogeneous individuals and categories negatively defined by social privation, material need and symbolic deficit" (p. 246).

Arne Kalleberg has also deployed the term precarious work as employment that is "uncertain, unpredictable, and risky from the point of the worker" (2008, p. 2). According to Kalleberg, employment precariousness is characterized by a situation in which one is involuntarily unemployed or underemployed; and/or fearful of the prospect of losing one's job; and/or facing few alternative employment arrangements and therefore forced into undesirable work conditions (p. 2). These circumstances are rendered even more trying in the absence of public safety nets and collective bargaining possibilities. Precariousness affects not only one's work and workplace experience, but also carries over into the nonwork spheres of life. As Bourdieu (1998) has suggested, "the awareness of [job insecurity] never goes away: it is present at every moment in everyone's mind....It pervades both the conscious and the unconscious mind" (p. 82; my italics). Adeline's story illustrates the draining nature of this constant state of anticipation, hope, and uncertainty. 
As Kalleberg seems to suggest, there is something about the nature of employment in the US that makes it particularly precarious. In contrast to Wacquant's conclusions (2004), precarity characterizes not only the experience of the urban poor who are acted upon by the state, but it also seems to capture the experiences of those at the economic center, and who are subject to the forces of capital. The story of Adeline's descent from a highly valued and regularly employed temp to one who waits anxiously by the phone for an unlikely call from the temp agency, illustrates vividly the texture of that precarity. For the purposes of this study, I adopt Kalleberg's definition of employment precarity to characterize the type of structural vulnerability that workers are increasingly facing today. Moreover, I find that precariousness is systematically cultivated in the contemporary economy, both among the skilled and less-skilled workers, ${ }^{1}$ as well as among men and women of both socioeconomically privileged and disadvantaged backgrounds. Specifically, the analysis of a temporary staffing company's daily operations can serve as a case-study of how, despite the opportunities it may provide to workers in a restrictive labor market, the agency cultivates precariousness among both core and peripheral workers in the pursuit of profit.

\section{Restoring agency to the agency}

In April 2006, 2.3\% of total employment consisted of workers employed through a temp agency $^{2}$ (Mishel et al. 2007, p. 239, fig. 4T). Temporary help agency offices exploded from 600 in the 1960 s to nearly 40,000 today. Since the 1960 s, the industry's annual earnings have increased nearly 300-fold to $\$ 72.3$ billion today (Smith and Neuwirth 2008, p. 192, footnote 3). Many scholars are attributing this phenomenal growth to more demand, as firms increasingly feel attracted to and comfortable with flexible work arrangements. TSAs reduce the costs of recruitment, screening, and firing workers; they enable firms to reserve higher wages and benefits for permanent workers, while providing a worse compensation scheme for less legally protected temporary workers. They also help adjust firms' workforce sizes to accommodate fluctuating workloads (Segal and Sullivan 1997; Smith 1998; Houseman and Polivka 1998; Kalleberg 2000).

While, certainly, the increased use of temporary and contract workers can, in part, be attributed to firms' cost-benefit calculations, the basic principles of economic sociology also suggest another approach. Most notably, Peck and Theodore (2002a, b, 2006) have challenged the image of the TSA as a passive "product of the market," a neutral labor market intermediary. They have shown how demand-focused explanations of temp agency growth tend to echo the misleading discourse that the temporary staffing industry (TSI) is itself trying to promote. By comparing the official industry rhetoric against its activity both historically and in the contemporary labor market, Peck and Theodore illustrate the extent to which the THI tries to hide its market-making practices.

\footnotetext{
${ }^{1}$ Certainly, the category of "unskilled" is empirically problematic since all jobs require skill. I use the terms skilled and unskilled to differentiate between work that on the one hand, requires one to have previous experience, knowledge of dining/service etiquette, in particular, norms involved in interaction with customers, and on the other, work that does not require any previous experience, education, or cultural capital.

2 I refer to "temporary staffing agency," "TSA," "temporary staffing company" and "agency" interchangeably. The terms "client" and "client company" refer to the firm which utilizes the services of an agency. I also use "candidate," "temp" and "employee" interchangeably to refer to temporary workers who are employed by and are on the payroll of temp agencies, but who work at client sites.
} 
Other scholars (Gottfried 1991; Ofstead 1999; Gonos 2000; Smith and Neuwirth 2008) have also joined the cause to restore agency to the agency. Their studies have focused on what TSAs, both on the individual organizational level and on the industry level, do. How do these entities make markets? More broadly, how do they create the conditions in which they may flourish unhindered? These studies have refocused attention on the staffing agency itself by making the agency and/or the larger industry the central object of study (instead of, for example, client companies or temp workers). Smith and Neuwirth's (2008) recent publication perhaps best captures this focal shift, for it draws on ethnographic work at Select Labor, a TSA located in the Silicon Valley.

Smith and Neuwirth found that Select Labor was in the business of "build[ing], cultivat [ing] marketable workforces" by actively recruiting candidates instead of letting them come in on their own; by distinguishing the "good" temp from the "bad warm-body"; by realigning worker aspirations to the agency's goals and by deploying "strategic personalism" 3 in order to gain worker consent. At the same time, the agency mediates between the client employer and the temp by "softening" tough and/or negligent managers and working with human resources departments of client companies to smooth the transition of temp workers into client work sites. Ironically, according to Smith and Neuwirth, while profit motivated Select Labor's decisions and practices, the agency benefited workers. Despite the fact that most workers prefer permanent employment to a series of unpredictable temporary gigs and despite their "constrained" nature, the agency provided their temps with "transitional mobility opportunities" (p. 150). Based on this fieldwork and the findings of other researchers, Smith and Neuwirth conclude that TSAs can help job seekers to:

1) get past barriers related to social discrimination;

2) overcome their lack of social capital, which is hindering them from finding work;

3) develop skills;

4) minimize gaps of unemployment in their job history; and

5) get placed in jobs that hold feasible possibility for transition into permanent positions.

Casting all temporary employment as inherently "bad," the authors argue, misses the assistance and resources these agencies provide workers who otherwise, by virtue of their social location, face a very restricted labor market. Given the unfortunate reality of the labor market today, the services temporary help agencies provide, in the last instance, help to create some "institutional protection for a great many workers" (p. 176).

At my field site, Instant People (IP), the daily work of the agency staff also resulted in transitional mobility for many workers. Indeed, this may explain why many workers continued to use the agency's services, recommended IP to their loved ones, and, in gratitude for the jobs they received, some even volunteered to post IP fliers in the lobbies of their apartment buildings. However, despite the immediate assistance the agency provides in a restricted market and the genuineness of the gratitude that these services elicit in workers, we need to also acknowledge how this industry affects the realities of the deregulated labor market.

\footnotetext{
${ }^{3}$ That is, employers “'engage in emotional labor and create a homelike work environment in order to ensure workers' complicity with management authority and to increase productivity" (p. 92). Smith and Neuwirth identified four types of strategic personalism regularly deployed by the company: staff visits to the client site in order to observe the temp at work; emotion work vis-à-vis the temp; the provision of ad-hoc but simple services to the temp; and honoring requests to employ family members.
} 
In a word, I found that IP uses multiple strategies to exploit and reproduce contingency. Like Purser's (2006, 2009) discussion of “flexploitation" exercised by day labor companies, a staffing company that must contend daily with tight profit margins and high competition, has to prioritize the client firm's needs over that of the employees and deploy various chiseling strategies ${ }^{4}$ to extend their margins. Even when a TSA does provide the first four opportunities of transitional mobility outlined above, they do so in a way that enhances the long-term precariousness of the worker. The structural vulnerability already produced by the labor market is the basis of temp agency exploitation. But the agency, by way of its efforts to chisel out a little more profit, also perpetuates that vulnerability. ${ }^{5}$ The agency reproduces contingency, most centrally, by putting obstacles in front of the "good temp" who wishes to use temporary employment as a bridge to permanent work. When we account for the agency's interests, as a profit-motivated firm operating in a highly competitive industry, the "perks" that come with being a temp are recast in a different light. The realized - and frequently, only promised - rewards of the agency help secure worker consent and draw her back again and again to the temp agency for her next paycheck. This is not only true for low-skilled workers with spotty employment histories, who have spent their lives in marginalized communities and carry the indelible mark of a criminal record. But, as I argue, the staffing company can and does render precarious the highly-skilled workers with privileged backgrounds as well.

\section{"Placing the right people in the right jobs for the right reasons"6}

My data come from participant observation at Instant People, the pseudonym for the corporate office of a boutique staffing company that specializes in the food and hospitality industries in a West Coast city. The company was bought by the owner, Sean, ${ }^{7}$ in late 2004 when it was, as he characterized it, just a "dinky" office "in the middle of the homeless" population. Just when he was regretting his decision to become a staffing company owner, Sean chanced on an easy pot of money: the workers at a large local hospital were planning to strike and the hospital desperately needed a few hundred scab workers. He felt like he had "won the lottery" when the strike ran nearly 9 weeks, and Sean charged 300\% markups to the client. At the end of the ordeal, after several violent incidents between strikers and his picket-crossing temps, he had made $\$ 850,000$ in profits. He used this money to move to a larger office in a nicer part of town, purchase computers, and hire a larger staff.

During my fieldwork, the central IP office had a total of five full-time staff members, in addition to Sean. Janet, Darren, and Teresa were all "account managers," acting as liaisons between client companies and the agency. Jessica occasionally did account management, but her primary responsibility was employee relations while Leah was in charge of payroll.

\footnotetext{
${ }^{4} \mathrm{I}$ thank Reviewer A for this term, which neatly captures the nature of the agency's daily concerns and practices.

${ }^{5}$ Purser's (2009) study of a formal day labor company and one of the largest private employers in the US, captures the astonishing way in which day labor perpetuates precarious employment and reproduces the "dispossession of the urban poor" on a daily basis (p. 19). Day labor, she argues, produces the "circle of dispossession" or "a state of dependency on the very thing that produces dispossession that reproduces their dependency on it" (p. 200). As I will show, Instant People also produces a similar cycle of precarity not only among its socioeconomically marginalized workers but also, and more actively, among its "core" workers of privileged background.

${ }^{6}$ This is the motto of Instant People, which new recruits are encouraged to recite during orientation and remember afterwards.

${ }^{7}$ All names are pseudonyms.
} 
In addition, a temporary employee came in occasionally to assist the account managers and Jessica. During my time there, a receptionist was hired, but then fired 2 months later. Over the course of the previous 2 years, Sean had opened up three more IP offices throughout the state, each of which had only two staff members. The company's total profit for the 2008 fiscal year was roughly $\$ 2$ million.

The agency's clients span all industries and include such institutions as restaurants, fine catering companies, country clubs, healthcare sites, and hotels. Currently, its most important clients are two multinational food services corporations, a leading biotechnology corporation and a university, from which the agency receives significant job orders each week. The company dispatches the full gamut of cooks - executive chef to grill cooks - along with waitstaff of varying skill levels and work histories, cashiers, concessionaires, bartenders, baristas and armies of dishwashers/utility workers. The hourly wages the agency pays run between $\$ 9$ and $\$ 17$ for regular temps, but can go as high as \$22 for "captains" or temps with supervisory responsibilities. The markups for clients tend to range from $50 \%$ to $60 \%$.

For 3 months, I worked two and occasionally three full workdays each week as a temporary employee in the corporate office. I initially contacted Sean in May 2008 to interview him, as part of my larger project to interview owners of staffing companies in the area. He was interested in my project and suggested that I could work for him then. In early September, I took him up on the offer. At Instant People's main office, I did mundane, mind-numbing tasks such as photocopying, data entry, and sorting paychecks in addition to more interesting ones that provided valuable insight into the daily operation of a staffing company. On the client side, I have taken job orders from clients, negotiated with client managers about which employees to dispatch them, and composed emails to prospective clients in an effort to market the agency's services. On the candidate side, I have helped with the intake process, coordinated orientation and training sessions, assigned jobs to workers, and, most challengingly, attempted to calm angry employees who called in with an array of complaints, most frequently involving disappeared paychecks, account managers who never return their calls, and the dearth of jobs. One hectic day, I managed the office by myself, answering phones and dealing with last-minute call-offs, as the entire staff of IP went on a three-hour food-tasting extravaganza for "team-building" purposes.

The project fast-turned into carnal sociology, as I put my "own organism, sensibility, and incarnate intelligence at the epicenter of the array of material and symbolic forces" that I intended to analyze (Wacquant 2004, p. viii). In the heat of the moment, I found myself adopting the agency staff's moral framework and general dispositions vis-à-vis clients and candidates. It allowed me to endure the trials and tribulations of being an agency representative. While emotionally trying, the experience did enrich my understanding of the temp agency's cognitive and moral universe. Just as Purser (2009) found that the day labor company she studied portrayed itself as an "altruistic organization" and packaged day labor as a "redemptive process" (p. 33), Instant People also relies heavily on a gift-giving and charity discourse. According to this trope, IP is a benevolent provider of employment to otherwise jobless men and women. For the agency staff, this discursive approach is not intended as an underhanded way to deceive workers into valuing the agency's efforts; rather, it is a discourse essential to the staff members' understanding of what they daily do for a living. Like them, I found myself categorizing workers into deserving and undeserving, worthy and unworthy, grateful and ungrateful, in order to negotiate the nonnegotiable fact that there are few jobs, but many unemployed and underemployed people all navigating an uncertain labor market.

In the following section, I argue that, despite their charitable discourse about being in the business of job creation, Instant People's daily operations are premised on sorting candidates 
into two groups - a core of permatemps and a surplus or peripheral group - which are then made precarious. That is, instead of weeding out weaker applicants and cultivating the promising temps as was the case in Smith and Neuwirth's field site, Instant People divides all its "hired" employees into two groups which the agency intends to utilize differently. Ultimately, however, both groups are rendered precarious. To illustrate this process, I show in the sections thereafter how peripheral workers, who rarely receive job assignments in the first place, are institutionally policed when they are allocated jobs. I discuss how core workers as valued temps face limited mobility in terms of transitioning into permanent jobs, or even advancing within the world of temporary work. I explore the ways in which both core and peripheral workers are subject to high levels of surveillance at client sites. In the concluding section, I turn briefly to Instant People's future projects to mine new spaces for work in order to emphasize the centrality of market-making for these agencies.

\section{Cultivating the core and periphery}

The first time I ever visited Instant People, I encountered the fuzzy boundary between hiring workers and job allocation. Sean and I settled into his office chairs so that I could interview him. Before I had a chance to ask him my first question, he began, "look, let me just say that I'm in this business because I like finding people jobs." The language of care, compassion and altruism saturated the rest of the interview, as he related story after story of disadvantaged people his company had hired.

Months later when I began my ethnographic work, I came to see the practices that served to buttress this discourse of care and paternalism. Every week, during a two-hour period designated as "open call," prospective candidates walked through company doors to apply for jobs. During my first experience with "open call," I was struck by the frenetic atmosphere of the office, as agency staff rushed to "process" everyone:

A swarm of men and women, dressed in bistros, half-tuxes, bow-ties, starched white shirts, polished shoes came through the IP office today...I count nearly 24 heads and feel the noticeable rise in room temperature with all the extra body heat. The office has turned into an assembly line of intake as we test and photograph prospective employees, photocopy ID cards, distribute applications and W-2 forms and interview everyone....At the end of the day, I feel satisfied that we managed to complete every intake thoroughly....Sean wanders over to my desk, and without my prompting, says with enthusiasm: "I'm a big fan of the underdog....These folks feel very grateful. I mean, we're giving them jobs."

The following Thursday, I typed up 22 offer letters addressed to the candidates the agency staff "hired." Indeed, on the surface, it did appear that on a weekly basis IP was in the charitable business of distributing jobs and enabling continuity in individuals' respective employment histories. The discourse of care and paternalism constantly evoked by the staff members was reinforced in material practices. The flurry of paperwork that prospective temps filled out and which the staff then reviewed, line by line, in addition to the other tiring, intensive, and meticulous work that they performed to complete the ritual of intake showed how much staff cared about candidates. What I soon discovered, however, was that the open call and orientation - that is, the entire set of practices that constituted "hiring"-masked the actual number of jobs as well as to whom this finite supply of jobs were allocated.

Instant People utilizes what I call an imitation logic in order to obscure the boundary between becoming a candidate or signing up for IP's services and actually getting a job. The 
content and order of the individual steps involved in the advertisement of the "job," the ritual of intake, the callback, the orientation, and the elaborate training procedures are set up to mimic what might happen in a traditional employment model. The agency even gives its employees "referral-type Instant People business cards" that they are encouraged to distribute among friends and companies - as if they were permanent employees of a firm. Unlike Select Labor, where agency representatives were instructed to explicitly educate potential candidates about how temporary employment works (Smith and Neuwirth 2008, p. 82), IP plays down the fact that it is a temp agency and that the jobs it will offer to most "hired" candidates are irregular assignments with little to no possibility of job security. During orientation, when Jessica did mention that it was IP and not the client firm who was the candidate's official employer, she quickly offered a glamorous analogy. "Just make believe that you're an athlete or movie actor," she told the candidates, "and we're your agent." When I asked her later why she used the analogy, she mentioned her discomfort with the term "agency" or "temp agency," preferring to elide IP's identification with THAs altogether. By deliberately emulating the rituals normally involved in permanent hiring and conceding only occasional remarks about the temporary nature of the jobs offered, the staff members try to normalize their intermediary presence vis-à-vis the candidates, so that they will, in Jessica's words, "take seriously" the agency's expectations and services. ${ }^{8}$ That is, these practices create the illusion of the availability of jobs and that jobs are systematically allocated on the basis of merit and procedure.

But the creation of a large labor pool given the dearth of jobs does not serve a purely symbolic function. ${ }^{9}$ It also has a practical purpose. Just as scholar Chris Forde (2001) has observed in his study of temp agencies in the UK, IP actively generates a surplus of workers "on the books," what I refer to as a peripheral group, without intending to find them all regular jobs. Instead, this stock of surplus labor is simply maintained so as to meet the fluctuating demands of clients. While Forde noted the deliberate creation of this surplus stock of underemployed workers, I argue that IP also creates a stock of permatemps who get priority when jobs do become available. Only about a quarter to a third of the actual candidate base are regularly utilized. ${ }^{10}$ IP either never or very infrequently assigns jobs to the rest. ${ }^{11}$

\footnotetext{
${ }^{8}$ The extent to which the agency is successful in achieving this aim is an open question. I haven't systematically interviewed Instant People temps and cannot infer what they think about the agency. I suspect that some permatemps feel loyal to the agency. I witnessed several times when workers came to the office bearing cards or gifts or simply warm salutations for account managers. Jessica, the employee relations manager, has many times insisted on the need to maintain an image of professionalism vis-à-vis the candidate so as to have the agency be treated like any other workplace, garnering professional conduct from its temporary employees.

9 This is similar to Purser's (2006) extension of Bartley and Roberts (2006) analysis of the "list" of workers at a day labor center. The list contains the names of the job-seekers who showed up at the center, in the order of their arrival; however, many have observed that the list plays little to no role in dispatchers' actual decisions about job allocation. Purser argues that in addition to serving a mere "symbolic" function, it has the "practical function of ensuring that the company is able to make available a sufficiently large pool of jobseekers" so as to "provide labor "on demand"” (p. 11).

${ }^{10}$ To make this calculation, I looked at 20 weeks (five months) of payroll information for the year 2008. I picked two high-season months (July and December), two low-season months (February and March) and one month that was considered "in-between" by staff (October), in terms of client demand for company services. I tracked the frequency of names that appeared across days of the week, weeks of the month, and then across months. I defined "core" as having worked a job assignment twice or more per week across at least three weeks that month, and "periphery" as anything less than that. I found that, on average, between $65 \%$ and $75 \%$ of the names appear very infrequently. Then I took a random sample of ten names from each group and looked at their profiles, paying particular attention to their wages, their past work experience, the staff's qualitative evaluation of the worker's behavior, and whether or not they have a criminal background.

${ }^{11}$ A tragicomic ritual in the office involved the staff listening on speakerphone to the "availability" status of one particularly underemployed and insistent candidate, Timothy. The epigraph is the message he left.
} 
The peripheral group of surplus workers tend to be less skilled, more likely to perform back-of-the-house ${ }^{12}$ work, and tend to have the mark of a criminal record. Conversely, those candidates deemed reliable, hardworking, and professional constitute the core group, and receive regular job assignments. They tend to be skilled, work in the front-of-the-house, and have several years of service work experience. The core worker, who is preferred by client companies and thus highly valued by the staffing company, is likely to be fashioned into a permanent temporary worker.

Why does the agency create a core set of permatemps? First, the nature of the dayto-day placement process, during which agency staff scramble to fill job orders, reveals that it is easier, quicker, and perceivably safer to rely on a privileged core of employees rather than the whole database of candidates. If an employee has proven her reliability in the past, she's preferred to another "untried" worker who might potentially require a lot of "babysitting" or "handholding." During weekly staff meetings, daily lunches, emails, and in informal spoken exchanges, staff members convey to each other their experiences of workers, their evaluations of the workers' behavior and backgrounds, and what their clients have said or not said about their workers. On the basis of these daily practices, a collective knowledge is produced and staff end up cultivating a core of permatemps.

This collective knowledge that draws the boundary between core and periphery is daily reinforced by matchmaking games that staff members play in order to make decisions about job allocations. Field notes from my first week reveal the thrill of one such instance:

Towards $5 \mathrm{pm}$, the office is abuzz as Janet, Teresa, and Jessica try to find someone to replace a candidate who has just called to cancel. They need to locate a server for a gig this evening....They urge each other to think fast. "Come on! Who can we call?" Names are shouted across the office: "How about...?" "No, she's already busy with something else today." "No, I already called him." "Come on, people-THINK!" While I know they're worried about not finding someone on time, there's a jovial manner to this last-minute matching fiasco. It feels like a game.

In a stressful environment where ad hoc cancellations and replacements are the norm, memory-reliant "matchmaking games" are a welcome respite from the regular anxiety of unfilled job orders. In addition to doing systematic searches on the database, staff members come to rely on the collective knowledge that they've assembled about candidates through their conversations with each other. The core candidates' names, frequently mentioned in positive terms, become very familiar to everyone over time. In playing these matchmaking games, staff members then end up daily reproducing the separation of core from periphery.

Second, as on-site employers increasingly pass on the costs of unemployment insurance to temp agencies (Mehta and Theodore 2002-3), staffing companies like Instant People retaliate by taking advantage of the minimum earnings tests. Historically, as Mehta and

\footnotetext{
12 "Back of the house" work tends to involve little interaction with customers, and takes place in the kitchen; generally, this work includes dishwashing and cooking. "Front of the house" work is primarily the work of serving customers, and requires more focus on self-presentation and the minutiae of service etiquette. Again, the divide between back and front of the house does not exactly match up with the division between the periphery and core respectively. As I indicate later, skilled chefs perform back of the house work alongside dishwashers, but the former are among IP's most highly valued workers while the latter are disposable labor. Similarly, while dishwashers tend to make up the majority of periphery workers, well-liked dishwashers can turn into core permatemps. Therefore, it is a complex intersection of several factors (in addition to the nature of the work one is assigned) that determine the characteristics of the core group.
} 
Theodore have shown, workers employed through temp agencies have the lowest rate of unemployment insurance recipiency among contingent workers. They've attributed this tendency to the fact that because temps only work part of the year, they're unable to meet the minimum earnings test. This "test" or threshold is used by the state to measure a worker's level of attachment to the labor force and partially determines whether the worker is eligible for this benefit. By not regularly assigning the majority of its "hired" candidates to jobs, Instant People effectively reduces the likelihood that its candidates will meet the minimal earnings requirements. ${ }^{13}$ In this way, the agency avoids paying unemployment insurance on a substantial part of its "hired" workers.

In mimicry of the standard employment model, the agency effectively blurs the distinction between its hiring and job allocation practices. While the agency is certainly a place of much assembly line activity, little of that quotidian bustle is actually dedicated to systematically reducing underemployment or filling gaps in peoples' employment histories. Rational job allocation, as others have noted, is an illusion at this site as well (Bartley and Roberts 2006; Purser 2006; Purser 2009; Forde 2001). Rather, the specter of falling gross margins motivates Instant People-as well as other profit-motivated boutique staffing firms operating under a recession economy - to look for ways to circumvent risks and costs associated with employment. Having established the way IP sorts its workers, I turn now to one of the ways in which the peripheral worker is cultivated into a precariat.

\section{Outsourcing discipline, control and surveillance}

Smith and Neuwirth (2008) mention that TSAs enable marginalized employees to get past employment barriers. Instant People's "parolee-friendly" approach fits this characterization of temp agencies: on a weekly basis, IP "hires" anywhere between five to ten individuals who would be deemed too high-risk and/or subject to discriminatory screening and hiring practices elsewhere due to their criminal records (Bernasek and Kinnear 1999; Pager 2003). The employee relations manager estimates that IP owes at least 20 to $25 \%$ of its profits for the 2008 fiscal year to the dishwashers, utility workers, and cooks who have spent time in prison. This percentage was higher when IP was first established, but has diminished over the years as the agency has recruited from less socially-stigmatized and more skilled sources of labor including culinary schools and college campus job fairs. Yet, despite this, the agency cultivates its ties to organizations that work to rehabilitate ex-offenders, treat former substance addicts, and feed and shelter the homeless. ${ }^{14}$

\footnotetext{
${ }^{13}$ Mehta and Theodore (2002-3) have also noted that the inconsistency of temporary work assignments makes it difficult to meet earnings thresholds which could on average be met by minimum wage workers "if they work twenty hours per week for more than forty weeks during the base period" (p. 105). This tendency, coupled with the fact that temp workers in general earn less than their permanent counterparts, makes temp workers less likely to meet earnings thresholds and be deemed adequately attached to the labor force. One feels the full brunt of these disadvantages if one happens to also be a peripheral or surplus worker for the temp agency.

${ }^{14}$ Purser (2009) also discusses the partnership forged between day labor companies and non-profit and staterun prisoner re-entry organizations, which are daily reflected in the direct cooperation between parole officers and agency dispatchers. Like her study, my observations also lend further evidence to Wacquant's (2008b) insightful linkage of imprisonment to contingent employment.
} 
Scholars have discussed the unique "triangular employment relations" that characterize temporary work, in which the de jure employer is separate from the de facto or "supervising" employer (Kalleberg et al 2000). Indeed, Smith's (1997) interviews with temporary workers revealed how the complexity of the employment contract and the resulting ambiguous identity of the "true" employer facilitated the exploitation and marginalization of temps. In the case of Instant People, however, the relationship is further complicated by a fourth institution which supplies and sometimes even helps the agency police a desperate workforce.

On its website, Instant People proudly advertises its relationship with both for-profit and non-profit community organizations. ${ }^{15}$ Sean sits on the board of directors of the nonprofit agency West Service League (WSL). Its services include "extensive in-jail and postrelease education" rehabilitation, transitional housing, "life skills training," and perhaps most importantly, "job development and job placement," according to a WSL newsletter. Despite agency staff members' grumblings, the importance of these ties is not merely nominal. For example, IP paid for a Halloween Party, which was attended by WSL staff, donors as well as the individuals who use WSL's services. It was important for Sean to make this "P[ublic] R[elations] move," in order to cultivate organizational ties. Also, Sean spends a lot of time serving on the board of JobOrg, another non-profit organization that provides job training programs and "life skills" workshops for the underprivileged. Through JobOrg, an individual may gain vocational skills as a cook, for example, and then be directed to the doors of IP for temporary assignments. Serenity House is a drug and alcohol treatment center that provides shelter as well as outpatient services such as counseling and vocational training to its members. During my tenure at IP, I saw these organizations' names appear each week on job applications where applicants were asked to write down their current addresses and/or note from where they were referred to Instant People. However, I most frequently saw the street address for the local branch of Dwight Correction Company and for this reason I focus on the agency's relationship with this particular institution.

Dwight Correction Company (DCC), a private treatment and correctional facility with branches all over the US, is also referred to as a "halfway house" among agency personnel and candidates. Instant People, since its founding, has relied on DCC for a steady stream of workers who might have otherwise experienced difficulty securing permanent jobs. And while today these workers tend to find themselves in the agency's peripheral group, they are still a source of profit because they constitute a large labor force available on short notice, such as for a strike or other large event. Darren, an account manager and a former DCC resident himself, frequently gives inspirational speeches to audiences at DCC, encouraging them to change their lives by seeking employment through IP. Weekly, prospective candidates of all skill backgrounds write down DCC's local address and phone number as their contact information on IP job applications. Yet, despite the agency's progressive rhetoric about helping people with "checkered pasts" DCC are a constant source of complaints and frustration for agency staff. Be it their physical appearance, their style of self-presentation, their lack of work experience and/or the quality of their job performance, halfway house residents are seen as a mixed blessing for Instant People's bottom line. Moreover, client companies have sundry reactions to the

\footnotetext{
${ }^{15}$ Pseudonyms are used for all organizations mentioned in this section.

${ }^{16}$ This is Sean's favored euphemism to characterize halfway-house residents as well as others referred from WSL, Serenity Home and JobOrg.
} 
possibility of receiving temp workers who have been incarcerated. ${ }^{17}$ Why, then, does IP insist on utilizing this source of labor?

Instant People can outsource worker-disciplinary tasks to Dwight Correction Company, while taking advantage of the desperation of partially-incarcerated men and women. As a minimum-security facility, DCC does not allow "residents" to freely leave the halfway house. In other words, IP's "gift" to DCC residents is more than an unsteady stream of job assignments; it also is a gift of irregular but precious exit from institutionalized life. Unsurprisingly, in return, Instant People finds in DCC a pool of disciplined workers who are much more constrained in their ability to resist the wiles of the temp agency. What scholar Gottfried (1991) has identified as temp workers' bargaining chips vis-à-vis the temp agency, are simply not available to DCC residents. Given their marginalized position in the labor market, they cannot "negotiat[e] for more desirable assignments" or ask for pay raises. Account managers made this topic a frequent source of banter, as in the following exchange about an ex-felon:

Jessica He worked for \$1 [per hour while incarcerated.]

Janet No, probably just 30 cents.

Teresa Let's hire him—quick!

Moreover, these men and women are less likely to refuse work assignments. While perhaps they may co-register with other temp agencies, they are unlikely to "play one [agency] against the other" given that they are considered disposable labor from the standpoint of IP and most likely, other TSAs (p. 710). In addition, it is unlikely for parolees to threaten to terminate their employment with Instant People for a permanent position elsewhere, since even entry-level service-sector permanent jobs for individuals with criminal records are fairly inaccessible (Pager 2003).

Furthermore, the repercussions of being a "bad" temp - that is, an employee who does not meet the explicit and implicit ${ }^{18}$ expectations of the agency-are amplified for halfway house residents. When a parolee misses a job assignment, Instant People works closely

\footnotetext{
${ }^{17}$ Sean himself referred to these workers as a "mixed blessing" in the context of a SEIU UHW-led hospital strike in 2008. Instant People received a large order for "food and dietician" scab workers (dishwashers and cafeteria workers) less than a week before the scheduled strike. Sean was able to quickly procure 22 workers after a call to DCC. However, when hospital management realized that the requisite tuberculosis tests of the scab workers bore the mark of prison records, the situation nearly turned into a crisis. Thanks to Sean's charismatic but firm demeanor, he effectively "negotiated" with the hospital. In crunch mode, the hospital pretended it had never seen the TB records and accepted the scab workers. From the viewpoint of the temp agency, this situation illustrates both the conveniences and inconveniences associated with being a "paroleefriendly" institution. On the one hand, the agency could tap this institutional resource, meet a stopgap demand in record time and make $\$ 2600$ in profits. On the other hand, it forces the agency into risky situations. The agency must do "culture work" on clients about the reliability and work ethic of ex-offenders. Or, the agency must simply keep quiet about its labor sources, in hopes that the client will not realize the backgrounds of the temp workers, but then effectively risk good relations and future partnership with the client if they do find out.

18 "Explicit" expectations are the responsibilities outlined in orientation packets for candidates - such as calling at least 24 hours ahead of a scheduled job assignment to cancel. An "implicit" expectation is one that is not outwardly expressed to the candidate by the agency staff. However, in conversations among staff personnel, it becomes clear that these factors (which generally ease the job of the account manager) play an important role in an account manager's decision about how to allocate jobs. For example, while the agency advertises its services to candidates by glamorizing the flexibility temp work affords an individual, this is paralleled by the "implicit" expectation that when called about a job, the temp should do her best to accept the assignment. Teresa has explicitly reminded the account managers to note in candidates' profiles in the database if they've refused job assignments more than two times. During the rush to fill job orders, an agency representative is more likely to avoid calling these marked individuals who have failed to meet the agency's implicit expectations.
} 
with parole officers (PO) to locate and discipline parolee workers. The following two vignettes illustrate this point.

On one sunny afternoon, a client informed Darren angrily that a candidate, José, hadn't shown up to work. Darren immediately called the halfway house and left a message. Within an hour, José's PO called back. Darren informed him that José hadn't showed up at the job site, and that Darren hadn't been able to reach him. The PO expressed surprise but thanked him for the information. Darren decided to "forgive" José and gave him a second chance when the PO called back to let him know that he had located and talked to Jose about his responsibilities as a parolee. Cloaked in the discourse of gift-giving and forgiveness, the temp agency and the halfway house effectively cornered and disciplined José.

On another occasion, Darren called a parolee employee, chiding him for not showing up at a gig. "Where were you, bro?... You had all day to call us [to let Instant People staff know he was going to miss work.]" When Darren found that he was not eliciting a heartfelt apology or an adequate excuse for the no-show, he relied on the threat of the PO to gain leverage over the situation.

Well, if you have your parole officer call the office and confirm that...then we can excuse it....Who's your PO? Out of which office? Got his number? I'll just call him. [Pauses and listens.] Ok, have him give us a call and we'll clear it. [Pauses.] You know, it's not my decision. Have the PO call and confirm. But I can't guarantee anything.

The PO did call back. After a brief exchange, Darren again decided against termination, but was hesitant to give the candidate any more job assignments. He let the PO know this decision, who noted it in the parolee's records. I overheard similar phone exchanges often during my fieldwork.

Instant People normally relies on its own capacity to contact and discipline a "no-show." With a non-parolee employee, the agency could punish the "bad" temp by matching her with undesirable job assignments or in most cases, terminating her employment with the agency. In the case of Dwight residents, as these vignettes illustrate, the agency was able to outsource the disciplining function to a much more powerful outside entity. So while men and women from Dwight Correction Company may occasionally be a source of headache to IP staff and a potential liability in the agency's relations with its client companies, they constitute a pool of surplus workers available for use on an infrequent basis. In other words, the halfway house serves as an important institution from which IP can procure workers, who, because of their marginalized positions in the labor market and society as a whole, are unable to deploy the individualized resistance techniques normally available to temp workers. In addition, IP can rely on DCC to keep its parolee-employees under close surveillance while also disciplining them with the indirect threat of prolonged incarceration. The traditional triangular relationship has effectively been replaced by a four-way relationship.

These practices that cultivate the policed peripheral worker, also, ironically serve as the material basis for the charity discourses that Instant People habitually deploys. But how does the staffing company treat its core workers, the men and women who tend not to be recruited from correction facilities, but from culinary schools?

\section{Obstructing temp-to-perm mobility}

Instant People, like many other staffing companies, tries to make its services attractive to both clients and candidates by advertising its alleged dedication to temp-to-perm mobility. To prospective clients, the agency emphasizes the possibility of utilizing the safer "try- 
before-you-buy" formula. On its marketing materials, for example, IP emphasizes the potential costs associated with permanently hiring an employee: "Waste no time or money on hiring, firing, advertising, interviews, applications, payroll, taxes, insurance claims, unemployment claims, uniforms, schedules, call offs, or phone tag." Instead, by being able to "road-test" or "test-drive" an employee, the client is guaranteed "no commitment until [the company is] certain it's a good fit!" To candidates, the agency emphasizes the very same possibility, as a potential reward for one's good work ethic. During job fairs with prospective candidates and orientations with hired candidates, agency staff members reiterate this opportunity to gain the consent of the worker.

However, while appearing to embrace temp-to-perm possibilities, it hurts the agency's bottom line to lose "good" temps through temp-to-perm mobility. ${ }^{19}$ From the vantage point of the agency, a temp-to-perm transition means one less valuable employee in their candidate base, but also a client who needs one less temp worker from the agency. Instant People thus utilizes two mechanisms to reduce the likelihood of this happening.

First, account managers try to strategically place high-caliber workers in different job sites from assignment to assignment. Frequently, account managers express their "anger" amongst themselves as they gossip of clients who have "stolen" valuable employees and advise each other on how to navigate possible temp-to-perm situations. This is done to reduce the possibility of a client "falling in love with" or "becoming attached to" a valuable candidate, while also preventing a candidate from ever becoming fully acclimated to any one worksite. For example, in one exchange between two account managers, Jessica announced to the office that the manager at the GAP, Vanessa, wanted a particularly well-liked employee again. Teresa warned Jessica to be careful and strategic with this client manager, recounting her previous experience of losing a good temp. "I'm mad at GAP for stealing him [a candidate]. They're not supposed to approach him, they're supposed to talk with us first. That's bullshit!" She then continued, "You can't just give her what she wants every time. Send her Joe [another candidate] instead." Such accusatory conversations were a frequent occurrence in the office, as agency staff tried to balance the agency's desire to satisfy a customer's repeated demand for the same employee against the agency's fear of losing a valuable employee to that satisfied customer. Even if the client is not necessarily interested in taking on a candidate permanently, they may want a familiar temp worker regularly so as to minimize training time and lessen the general risk associated with using a temp agency. At the same time, however, the temp agency is reluctant to fulfill these requests, fearing that eventually the client might want to hire the familiar and trusted temp permanently.

Second, the agency passes on the costs of "losing" a temp worker to the worker herself and the client so as to discourage temp-to-perm mobility. Three options are available when a client contemplates taking on a candidate permanently: a) the client may pay a finders' fee amounting to anywhere between $\$ 1500$ and $\$ 4000$ or $10 \%$ of the projected annual salary of the worker; b) the client may allow the candidate to work for them as a temp for three uninterrupted months, all the while paying Instant People the markup rate; or c) the candidate may terminate her relationship with the client and wait out 6 months, after which time the client may employ her directly. While there is light at the end of the tunnel, I've overheard many conversations in which candidates feel discouraged by the "options" they're given. If the client is unwilling to pay the hefty finders' fee, it requires of candidates either three more months of patient temp work, or six more months of potential unemployment.

\footnotetext{
${ }^{19}$ Vosko's (2000, p. 152) interviews with branch managers of Canadian temp agencies illustrate their ambivalence and "mixed emotions" toward temporary-to-permanent arrangements.
} 
Occasionally, the possibility of temp-to-perm mobility can give a temp worker considerable leverage in wage negotiations with the agency. While ultimately unsuccessful, the case of Jason Hill serves to illustrate the complex set of relationships and alliances that emerge from the triangular employment scheme.

Jason Hill is a skilled cook, a graduate of a culinary school and has years of experience working in restaurants. He moved here from the Midwest nearly 5 months ago and did not know where or how to start looking for work. Realizing that one needed "connections" to get hired at one of the area's top-ranked catering companies, he decided to temp for a while in order to cover his expenses while also networking his way into these catering companies. While he was outraged to learn the wage Instant People offered him, \$16 per hour, was only a fraction of what he had earned before, he eventually buckled under the pressure of uncertainty and unemployment. IP sent him to one of BioComp, a biotechnology company's many cafeterias, where he prepared breakfast, lunch and dinner between 4 and 5 days per week. One day, he walked into the agency's office asking for a raise. When the employee relations manager let him know that "\$16 is where we cap out," Jason hinted that BioComp had expressed interest in hiring him permanently. "If you won't raise my pay, I'll just work for them [as a permanent employee]." While Jessica told him that if BioComp was considering doing this, they were legally bound to a contract with IP, and as a client firm, they were obligated to go through a "process" before Jason could be permanently employed by BioComp.

This interaction was enough to send the agency staff into a frenzy. After Jason left the office, Sean furrowed his brow and raised his voice, "if he doesn't want to work for us, he doesn't have to." He chastised the account managers for sending Jason to BioComp all the time. In the meantime, Janet called the company to confirm whether what Jason had suggested was indeed true. She quickly reminded BioComp that they were bound by their contract to a set of stipulations. Much to the staff's relief, the client expressed satisfaction with Jason's job performance but was not interested in taking him on permanently. In fact, the client felt disconcerted by Jason's expectations and even expressed disapproval with Jason's bluff to get a wage raise. The next week, Jason began receiving lower ratings from BioComp; the only explanation provided by the client was that Jason sometimes acted "obnoxiously" towards his coworkers. Eventually, BioComp asked that Jason not return. Instant People happily placed him elsewhere; and having learned their lesson, the account managers tried hard not to give him regular employment at any one client site.

This scenario illustrates the complex set of conflicts and negotiations that result from the triangular employment schema. The temp-to-perm possibility provides the employee with leverage, but also puts the individual in a vulnerable position when the client expresses loyalty to the agency's side of the situation. Coupled with the financial disincentives the agency weaves into its client contract, the temp worker, even the skilled valuable one, is trapped in relative immobility. However, while Jason Hill was ultimately refused a wage increase, others are occasionally granted anywhere between $\$ 0.50$ to $\$ 2$ raises if they have stayed with Instant People for more than 6 months. How does this process work and what is the agency's role in this process?

\section{Mystifying the pay raise}

Instant People deploys a long and arduous bureaucratic procedure to delay and effectively deny most employees' requests for pay raises. The mystification of the pay raise, as a daily 
micro-strategy the agency deploys to cut costs, is not unlike the legalized mystification of the agency's markups. George Gonos (2000) has illustrated how as a result of the temporary help industry's protracted lobbying efforts in the mid-twentieth century, agencies today can charge unregulated markups to clients without disclosing its rates to workers. By mystifying fees and markups, Gonos argues, agencies today can legally "skim" off the top of workers' wages. An extension of this type of mystifying practice is, arguably, the lengthy but ultimately futile procedure workers must undertake to request a pay raise from the agency.

When a candidate asks for a pay raise, she is redirected to the central office's employee relations manager, to whom she must make her case. Afterwards, the candidate must fill out an elaborate self-scrutinizing form. She must rate herself on a scale of 1 to 10 on seventeen characteristics, including items like "leadership and integrity" and "having compassion and care for others." This is followed by three open-ended questions about her job interests, what she finds most difficult about her "job," and the types of experience and training that could help her now and later. All this information is then inputted into the "system." Despite all these elaborate practices, in reality, the decision to reward a pay raise is made on a different set of criteria. The candidate must have worked at least 3 months before they're eligible for a wage increase of just $\$ 1$ an hour. Moreover, they must be impressive on several counts including "client feedback, attitude, history, availability" and the vague but decisive state of "our [the agency's] needs." Fractions of a dollar may be rewarded for increased experience, improved self-presentation, reliability or regular access to a car. The candidate is kept in the dark about the basis for the decision in regards to her request. In the office procedural handbook, account managers are told to not "tell the employee what their new rate will be....[To] make the entire process fair and accurate, it should be done mathematically."

This bureaucratization of the process and its time-consuming "mathematical" basis effectively dilutes the vigor of the worker's request. She does not know how her request was "processed." In other instances when an account manager reveals parts of the real basis of the decision, she does so in a way that discourages the candidate from following through with her request. My field notes from mid-September capture one such interaction. I could record only the account manager's side of the phone conversation, but the obstructionism is clear

My guess is \$2 is...[she's interrupted]. Well, you're going to have to email our employee relations person. Her name is Jessica and her email address is jessica@instantpeople.com. Ok, you got it? Then we can get started on the process. [She pauses and listens.] But you haven't gotten graded by any of the clients. [Pause] No, she didn't ["she" probably refers to the client, EFE]. I've worked with Bette [the client] many times and she has a tendency to be forgetful. [Bette apparently didn't put in a rating.] Again, in order to start the review process you have to email Jessica. [pause] I honestly cannot remember you. There's no picture in our database of you. [She laughs]. I'm going to be honest with you, I don't see any "notes" ${ }^{20}$ here. [She laughs again nervously.] I've done bartending and I made the same wage.

\footnotetext{
${ }^{20}$ Instant People's database contains detailed information about the agency's candidates and clients. In each candidate's profile, there is a photograph of the candidate as well as a section of "notes" in which account managers are supposed to paste their email interactions with the candidate, in addition to writing in their general evaluations of the candidate's performance and reliability as well as their demeanor toward agency representatives.
} 
The account manager is able to use the "process" as a way to defer a decision about the request. At the same time, she is able to effectively shift responsibility of the decision to circumstances that are not directly under her control-whether other account managers have taken the time to fill in the requisite "notes" about the candidate and more importantly, whether clients have taken the time to evaluate this candidate. Each week clients are asked to provide a numerical evaluation or "ratings" of the employees they've received from Instant People. Only about a quarter of the agency's clients bother to do this. The rest simply ignore this step, or only put down evaluations for temps with whom they were not particularly impressed. The clients do not know that their ratings have consequences for the candidate's capacity to ask for a wage increase.

This uncertainty is then coupled with a lack of institutional or collective support for the legitimacy of the employee's demand. Since temp workers are usually limited to individualized strategies of resistance, they are forced to accept whatever decisions the agency makes. If the worker is indeed rewarded a raise, it is very nominal at best - the formal cutoff, according to the agency's handbook, is $\$ 16$ per hour. Like the ritual of intake and "hiring" practices, the procedures to request a pay raise mimic familiar practices from permanent employment. But in the parallel universe of temporary work, such practices create the illusion that upward mobility is possible, all the while reproducing structural vulnerability.

Having outlined the central ways in which both the core and peripheral precariats are cultivated through the practices of the staffing company, I turn in the next section to a control technique that affects both groups of workers at the site of work.

\section{Captains of surveillance}

Given that temp workers are dispatched to dispersed job sites, how does the agency address the problem of control? Gottfried (1991) argued that at the job sites, the "fragmented" nature of the temp labor process facilitated control. That is, isolated and in an unfamiliar worksite, without knowledge of standard practice and the average "output," and anonymous to one's coworkers, the temp worker is inclined to work quickly and intensively. Since Gottfried's writing, temporary staff agencies continue to find innovative ways to solve this problem of control. For example, agencies are increasingly using the practice of vendor-onpremises (VOPs), in which they establish offices on actual client work sites (Smith \& Neuwirth 2008). In the case of Select Labor, VOP set-ups facilitate direct assessment of client needs, negotiation between the employees and management as well as influence over the client's HR practices. But most importantly, VOP arrangements permit agency staff to be physically located at the work site, enabling close and immediate surveillance of the employees as they work. When workers first arrive on the site, they report to the VOP, where they receive an orientation packet and instructions about their specific job functions. Thereafter, the VOP personnel serve as another layer of supervision in addition to the client managers.

Instant People does not deploy VOP arrangements; they find it to be a costly practice. Moreover, in many cases, IP dispatches a crew of workers who already know each other from previous job assignments or who have shared experiences from open call, orientation, and training sessions. This is especially true in the case of skilled permatemps who become quite familiar with each other, occasionally translating these work acquaintanceships into friendships and even romantic relationships. In these instances of camaraderie, the possibility of creating a fragmented labor process is diminished. How does Instant People reintroduce fragmentation into the temp worker's experience and thus exercise control over her? 
For events that require more than three workers, the agency dispatches "captains" ${ }^{21}$ who are assigned the responsibility of supervising and managing other Instant People candidates. They note no-shows, tardy arrivals and they ensure that everyone is uniformed and "presentable." Captains direct workers to their assigned tasks and help them navigate the work site. In addition, captains are expected to arbitrate and settle any problems that may arise between client managers and workers, acting as representatives of IP staff. During my tenure at IP, there were several instances when captains sent home candidates who were deemed unfit to work, saving agency staff from performing the unpleasant task from a distance. In a sense, the agency hands over onsite disciplinary and supervisory functions to designated employees, which then solidify the divisions between temp workers. Candidates, even if among familiar coworkers, feel IP's presence at all times.

Moreover, captains serve as the "eyes and ears" of the agency. After an event, captains must report back to Instant People about how the event went, providing a brief evaluation of each candidate's "appearance and ability," and whether there were any problems. The following is a typical interaction between a captain and an account manager.

\begin{abstract}
Alex, a smiley and chatty young man who acted as captain arrives at the office to speak with Janet. For the "report," Janet encourages Alex to "tell [her] the little things." How presentable did they look? How messy were candidates' uniforms? Moreover, how well did each individual perform the job function? Was anyone particularly outstanding? The conversation turns light-hearted and gossipy as Alex recounts an odd incident he observed: a candidate apparently put his finger in the wine bottle as he tried to get a piece of the cork out. Laughter follows and Janet keeps asking, "what about Joe?" "Well, you know..." Alex begins. Janet listens intently and continues asking very pointed questions about each candidate.
\end{abstract}

Captains' reports are then scrutinized by account managers. Odd incidents, such as the one revealed in Alex's account, are noted in individuals' database profiles and read by the account managers across Instant People's different offices. Disconcerting incidents are discussed at staff meetings and serve as the basis for confronting and disciplining workers. Captains thus facilitate agency supervision of workers while also reintroducing fragmentation into the average temp's experience.

\title{
Conclusion
}

If, as I have argued, the systematic cultivation of employment precarity is imperative to extending profit margins, it is unsurprising that THAs like Instant People have devised

\footnotetext{
${ }^{21}$ Captains or temps with supervisory roles tend to be skilled servers, sometimes with bartending and/or cooking experience. Account managers make "captains" out of individuals who impress them with articulate answers and other "soft" skills. A captain is paid anywhere between $\$ 17$ and $\$ 22$ per hour, usually toward the higher end of the pay scale. While clients are charged between $\$ 21.50$ and $\$ 26$ for regular employees, they are charged $\$ 32$ to $\$ 35$ per hour for a captain. In the client contract, they are described as having the "added responsibility of overseeing staff check-in/out, assignments, cooperation, quality control and flow" and to "serve as a liaison between client and assigned employees." However, the captain's high wage is only granted on a job-to-job basis. In other words, there's no guarantee that she will be made captain on every job assignment.
} 
innovative practices to spread the scope of structural vulnerability. In the coming years, Sean plans to more properly transition from being a provider of "stop-gap workers" to a "staffing" company (Vosko 2000) which staffs client firms not only with its contingent workforce, but also with its permanent staff. He also plans to implement a regular "strike-planning specialization" program providing just-in-time scabs to companies. Sean's plans for his company reflect only two of the myriad directions that temp agencies have extended their services in an effort to cope with the industry's tight profit margins.

When we couple Instant People's planned services for the future with its current practices, it becomes clear how a labor broker can take advantage of existing structural vulnerabilities and then reproduce them. This does not mean, however, that in the meantime workers don't benefit from the resources and jobs the agency provides in the context of an ever more restricted labor market. Indeed, without instances of agencies assisting temporaries to find secure employment, without some viable opportunities for transitional mobility and institutional protection against involuntary unemployment, the agency would lack appeal to workers. But when we look underneath the surface of the agency's practices, we see a company that systematically produces precarity out of both skilled and less-skilled workers, ex-felons and non-felons.

This organized production of precarity is the very basis of the staffing company's profit. Under the discourse of charity and the active mimicry of traditional employment models, workers are sorted into a privileged core of permatemps who are highly valued by the agency, and a periphery, or a group of go-to workers, who provide the agency with numerical flexibility. The peripheral pool of labor is fashioned largely out of the temp agency's partnership with outside disciplinary institutions, effectively introducing a fourway employment relationship. Between the agency and the partner institution, the worker can be closely policed. Among the core workers, ironically, being a "good" or highly valued temp translates into immobility. The agency obstructs the transition to permanent work in an effort to maintain a reliable source of profit. The mystification around how requests for wage increases are handled is reminiscent of the mystification of the markup; while it appears to be a merit-based process, it obscures the fact that wages are capped. Moreover, the agency outsources supervisory roles to workers, effectively solving the problem of control while also sowing division among its candidates. In these ways, the agency cultivates the precarious worker.

The transitional mobility opportunities that the temporary help agency provides - such as overcoming discriminatory barriers and lack of social capital-are real enough. But the long-term and deeper structural consequences that it poses for the labor market and what it means to be "employed" merit reflection. I have argued that the very infrastructure of the temp agency is premised on generating precarity for profit, so that a worker faces "a mode of domination of a new kind" premised on the "rational management of insecurity" (Bourdieu 1998, p. 85).

Adeline's story may, unfortunately, become a familiar one.

Acknowledgements I am indebted to Gabe Hetland, Graham Hill, Mike Levien, Roi Livne, Kate Maich and Michael Burawoy for all their invaluable reflections and support throughout this project. I also thank the anonymous reviewers at Qualitative Sociology for their insightful comments.

Open Access This article is distributed under the terms of the Creative Commons Attribution Noncommercial License which permits any noncommercial use, distribution, and reproduction in any medium, provided the original author(s) and source are credited. 


\section{References}

Bartley, T., \& Roberts, W. (2006). Relational exploitation: The informal organization of day labor agencies. WorkingUSA, 9, 41-58.

Bernasek, A., \& Kinnear, D. (1999). Workers' willingness to accept contingent employment. Journal of Economic Issues, 33, 461-470.

Bourdieu, P. (1998). Acts of resistance: Against the tyranny of the market. New York: New.

Forde, C. (2001). Temporary arrangements: The activities of employment agencies in the UK. Work, Employment and Society: Journal of the British Sociological Association, 15, 631-644.

Gonos, G. (2000). 'Never a fee!': The miracle of postmodern temporary help. WorkingUSA, 4, 9-36.

Gottfried, H. (1991). Mechanisms of control in the temporary help service industry. Sociological Forum, 6 , 699-713.

Houseman, S., \& Polivka, A. (1998). The implications of flexible staffing arrangements for job security. US Department of Labor, Bureau of Labor Statistics, Office of Employment Research and Program Development.

Kalleberg, A. (2000). Nonstandard employment relations: Part-time, temporary and contract work. Annual Review of Sociology, 26, 341-465.

Kalleberg, A. (2008). 2008 Presidential address-Precarious work, insecure workers: Employment relations in transition. American Sociological Review, 74, 1-22.

Kalleberg, A., Reskin, B., \& Hudson, K. (2000). Bad jobs in America: Standard and nonstandard employment relation and job quality in the United States. American Sociological Review, 65, 256-278.

Mishel, L., Bernstein, J., \& Allegretto, S. (2007). The state of working America 2006/2007: An economic policy institute book. Ithaca: Cornell University, ILR.

Ofstead, C. (1999). Temporary help firms as entrepreneurial actors. Sociological Forum, 14, 273-294.

Osterman, P. (1999). Securing prosperity: The American labor market: How it has changed and what to do about it. Princeton: Princeton University.

Pager, D. (2003). The mark of a criminal record. American Journal of Sociology, 108, 937-975.

Peck, J. A., \& Theodore, N. (2002a). The temporary staffing industry: Growth imperatives and limits of contingency. Economic Geography, 78, 463-493.

Peck, J. A., \& Theodore, N. (2002b). Temped out? Industry rhetoric, labor regulation and economic restructuring in the temporary staffing business. Economic and Industrial Democracy, 23, 143-175.

Peck, J. A., \& Theodore, N. (2006). Flexible recession: The temporary staffing industry and mediated work in the United States. Cambridge Journal of Economics, 31, 1-22.

Purser, G. (2006). Waiting for work: An ethnography of a day labor agency. Institute for the Study of Social Change.

Purser, G. (2009). Labor on demand: Dispatching the urban poor. PhD diss., University of California at Berkeley.

Segal, L., \& Sullivan, D. (1997). The growth of temporary services work. Journal of Economic Perspectives, $11,117-136$.

Smith, V. (1997). New forms of work organization. Annual Review of Sociology, 23, 315-339.

Smith, V. (1998). The fractured world of the temporary worker: Power, participation, and fragmentation in the contemporary workplace. Social Problems, 45, 411-430.

Smith, V., \& Neuwirth, E. (2008). The good temp. Ithaca: ILR/Cornell University.

Vosko, L. (2000). Temporary work: The gendered rise of a precarious employment relationship. Toronto: University of Toronto.

Wacquant, L. (2004). Body and soul: Notebooks of an apprentice boxer. Oxford: Oxford University.

Wacquant, L. (2008a). Urban outcasts: A comparative sociology of advanced marginality. Malden: Polity.

Wacquant, L. (2008b). The place of the prison in the new government of poverty. In M. L. Frampton, I. H. López, \& J. Simon (Eds.), After the war on crime: Race, democracy and a new reconstruction (pp. 23-36). New York: New York University.

Emine Fidan Elcioglu is a doctoral student at the Department of Sociology at the University of California, Berkeley. Her research focuses on contingent work and political sociology. 